\title{
Chronicle of the West. Notes on the Uniqueness of Constructive Self-criticism and Freedom of Speech
}

\begin{abstract}
Built on field research as well as on readings, this article addresses geological, historical and political issues concerning the Western word, especially North America. A consideration to be borne in mind is: if the Western culture is so bad, as its detractors say, how to explain that such a great number of them prefer to live in... the West?!
\end{abstract}

Keywords: Western Culture, North America, Constructive Self-criticism, Freedom of Speech, Political Incorrectness

\author{
Volume 2 Issue 5 - 2018
}

João Vicente Ganzarolli de Oliveira
Professor and Researcher of the Tércio Pacitti Institute of the
Federal University of Rio de Janeiro, Brazil

\begin{abstract}
Correspondence: João Vicente Ganzarolli de Oliveira, Professor and Researcher of the Tércio Pacitti Institute of the Federal University of Rio de Janeiro, Brazil, 550, Cidade Universitária, Rio de Janeiro (RJ, 2 I94I-90I), Tel. +552 I - 39389600,Email jganzarolli@usa.com
\end{abstract}

Received:September 16, 2018 | Published: September 26, 2018

\section{Editorial}

If western culture is shown to be rich, it is because, even before the Enlightenment, it has tried to dissolve harmful simplifications through inquiry and the critical mind. Umberto Eco.

No! The Atlantic Ocean was definitely not the mare tenebrosum of which the myth created by the Carthaginian navigators in Antiquity told of. ${ }^{1}$ In 1492, the Genoese Navigator Christopher Columbus (14511506) proved that the Atlantic was not home to monsters and its shores did not represent the extreme limit of the emerged lands; it turned out to be the natural route that led to a new world, which Columbus thought was the eastern extension of Asia. ${ }^{2}$ Columbus, el Almirante, landed in a New World: America, vertical continental giant almost as large as horizontal Asia. Columbus connected historically lands that had been separated by geological forces, notably when Pangaea, the most recent of all supercontinents, began to break apart about 175 million years ago. ${ }^{3}$ Most of the ancient and medieval sages were wrong about the non-existence of inhabited lands in addition to those that comprised the Old World, namely parts of Europa, Africa and Asia. Far from being the mondo senza gente Dante Alighieri warned about in the Commedia, ${ }^{4}$ America, although in an uneven way, was populated from north to south and east to west; its inhabitants, mistakenly called "Indians" by Columbus (who thought to have landed in Asia), descended mainly from Siberian immigrants who, circa 40,000 years ago, began to cross the Behring Strait towards unknown and, of course, uncharted lands. Stretching nearly from pole to pole, America offers a scenario of extreme climatic variations, a phenomenon accentuated by the presence of vertical tertiary and colossal mountains on the rise,

\footnotetext{
${ }^{1}$ See, for instance, Avienus. Ora maritima, 108-109, and 380-9.

${ }^{2}$ One generation later the ocean expedition commanded by the Iberians Fernão de Magalhães and Juan Sebastián Elcano dispelled all doubts concerning the spherical shape of our planet (see Carmen Bernand \& Serge Gruzinski. Historia del Nuevo Mundo. Del Descubrimiento a la Conquista. La experiencia europea, $1492-1550$ [translated by Maria Antonia Bigorra], $2^{\text {nd }}$ ed., México, FCE, 2001, p. 372; and Victor W. von Hagen. Der Ruf der Neuen Welt. Deutsche bauen Amerika, Ilm, Knaur, 1974, pp. 38-39 and 42).

${ }^{3} \mathrm{Cf}$. Johannes Ebert et alii. Die grosse Chronik Weltgeschichte: vom Urknall zu den ersten Lebensformen: von 13.7 Mrd bis 292 Mio., Gütersloch/Munich, Wissen Media, 2008, t. I, pp. 28 et passim.

${ }^{4}$ Inferno, XXVI, 117.
}

linking in almost unbroken chain Alaska to Patagonia. ${ }^{5}$ Because of the high temperatures and the consequent rise in sea level, a great part of what today we call "America" was submerged land during much of the Cretaceous (c. 145 million years ago to c. 66 mya), geologic period in which non-avian dinosaurs began to sing their swansong; the Earth was on the eve of the Cenozoic ("New Life"), also known as the Age of Mammals, which extends from c. 66 mya to the present day. For Geology, those are short periods of time, since a hundred million years equal approximately $2 \%$ of the Earth's age; it is an age that falls almost entirely outside the scope of History and even Anthropology, considering that our earliest ancestors do not seem to be older than seven million years, which is a blink of an eye in our planet's life, let alone the Universe, with its 13,7 billion years of age. The arrival of man in America coincides with the appearance of our own species, the sole survivor among many others belonging to the genus Homo; the homo americanus was already a Homo sapiens sapiens. Writing, the raw material of History, is even more recent: it appeared for the first time in Mesopotamia about six thousand years ago and was invented in America only much later. Exception made to some Central American peoples (notably Mayans), the pre-Columbian world did not know the writing.

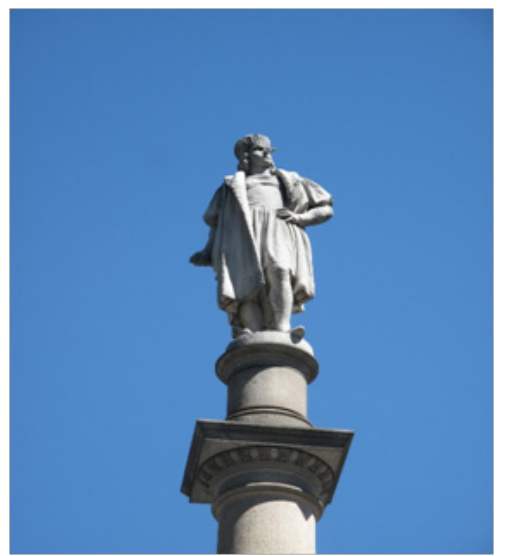

Christopher Columbus, sculpted by the Italian Gaetano Russo (Columbus Circle, New York) (Photo taken by the Author).

${ }^{5}$ See José Alcina Franch. El arte precolombino, Madrid, Akal, 1990, p. 48 


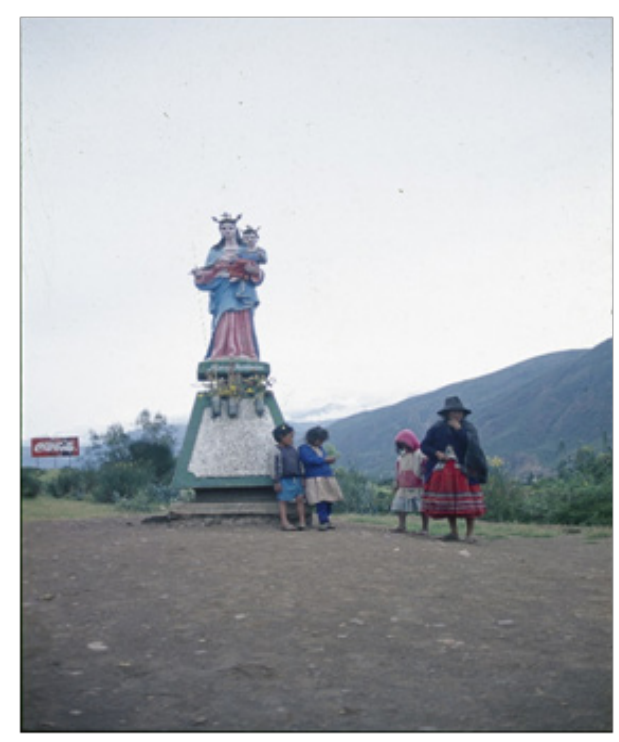

Descendants of the Incas, in northern Peru (Photo taken by the author).

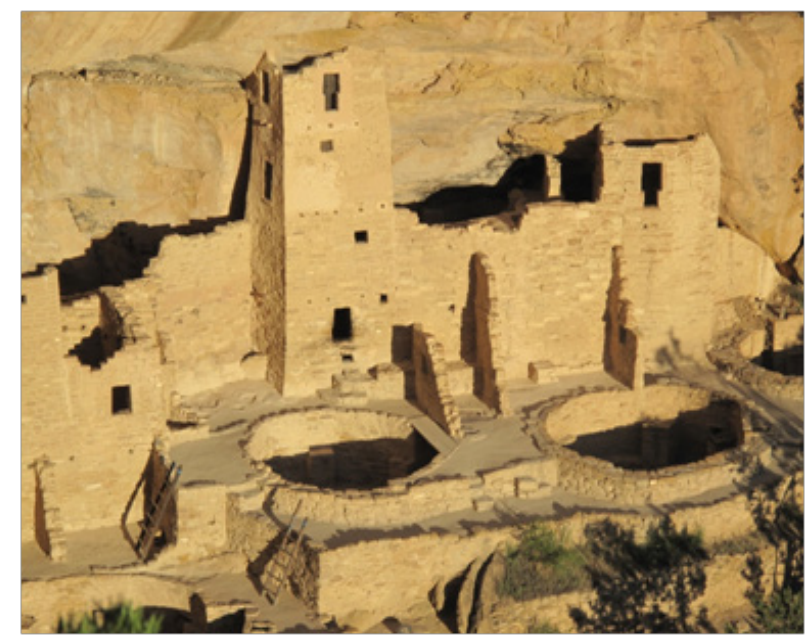

Mesa Verde national park, in Montezuma County, Colorado (USA) (Photo taken by the Author).

Some of the most sophisticated pre-Columbian cultures of North America had evolved within recently freed territories (geologically speaking) from oceanic waters. This is the case of the Amerindians called Anasazi ("the Ancients"), famous for their architecture, pottery and basketry. They already existed in c. $185 \mathrm{BC}$ and began to inhabit areas scattered through the present-day American states of Arizona, Colorado, New Mexico and Utah. Their descendants are the so-called Indians Pueblo, namely the Hopi, the Zuñi and other tribes of Rio Grande. Typically "pueblo" are the urban complexes of Mesa Verde, whose inhabitants disappeared mysteriously around $1300 \mathrm{AD}$, and of Taos, erected in c. $1450 \mathrm{AD}$. Made of clay, those are master pieces of architectonical simplicity that seem to spring out spontaneously from the very North American soil, a phenomenon which confirms the Greek tendency to see in art an imitation of nature, ${ }^{6}$ and which is particularly clear in lands like those, where the geological forces of destruction, construction and recycling of the rocks are so spectacularly inspiring. We can speak about cultural cringe to designate the kind of

${ }^{6} \mathrm{Cf}$., for instance, Aristotle. Ars poetica, 1448b; and Victor Goldschmidt. "Art et science", in Penser avec Aristote, Toulouse, Érès, 1991, p. 607. relationship between young nations like Canada, New Zealand and Australia with Great Britain (as a metropolis); however, the situation is quite another when we think of the United States. Already the early settlers believed they had a manifest destiny to fulfil in America - an idea that came from the Elizabethan geographer and writer Richard Haklyuts (1552-1616). In their understanding, those British migrants had the mission of creating a new and superior nation in America; adherents of the Puritan branch of Protestantism, they saw themselves as the New Israel, a God's chosen people for whom North America and its never-ending vastness were a promised land. The flip side of the coin was the so-called American paradox, that is to say, the exploitation of black slave labour and the almost complete annihilation of the North American Indians. ${ }^{7}$

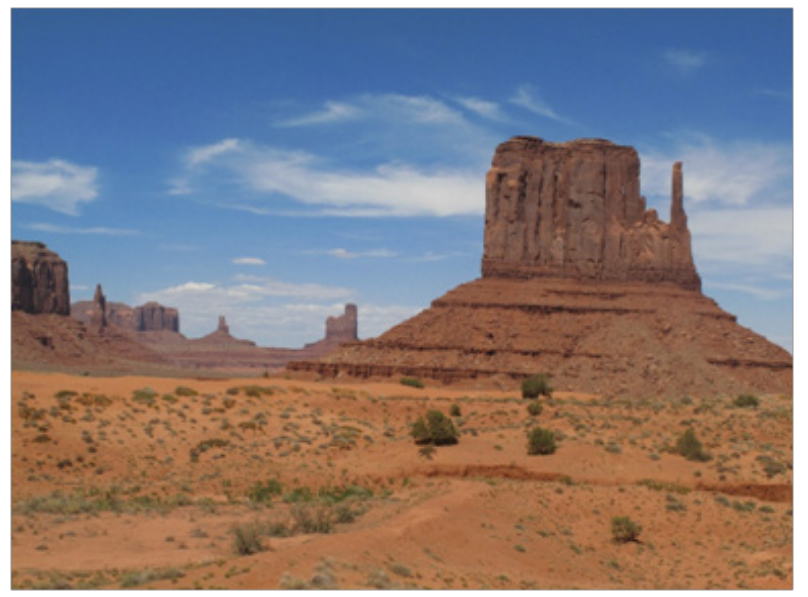

Monument Valley, on the Arizona-Utah border, one of North America's greatest geological icons. (Photo taken by the Author).

What stands out in such historical phenomena is the constructive self-criticism it encouraged, as well as the attempt to remedy the ills arisen, as well as the intention of not repeating them. The law of the strongest (and its corollary, that is to say, enslavement and exploitation in general, massacres and genocide) has usually been the lingua franca spoken by peoples in their relations among themselves. Consider the evils that Muslims (a category that already represents almost 30\% of the human race) have been causing until nowadays to Christians, Zoroastrians, Buddhists, Hindus and non-Muslims in general since Mohammed invented Islam, in the $7^{\text {th }}$ century of our era. ${ }^{8}$ Officially emerged in 1917, Communism, on its turn, has a death toll of more than 100 million people around the world. ${ }^{9}$ The evils committed by Europeans and their descendants in America are neither more reprehensible than those committed by American Indians or Negro Africans among themselves. ${ }^{10}$ The "noble savage" is nothing more

${ }^{7}$ Cf. Dee Brown. Bury My Heart at Wounded Knee, New York, Pocket Books, 1981, p. 143 et passim; and Horst Gründer. Eine Geschichte der europäischen Expansion: von Entdeckern und Eroberern zum Kolonialismus, Stuttgart, Theiss, 2003, pp. 76 and 80.

${ }^{8}$ What happens is that, since the birth of Islam, over 670 million non-Muslims have been killed by Muslims, a figure higher than that of the death toll of all human conflicts taken together since the dawn of History (cf. https:// themuslimissue.wordpress.com/2015/06/15/muslims-have-killed-over590-million-non-muslims-since-the-birth-of-mohammed/; and https:// en.wikipedia.org/wiki/List_of_wars_by_death_toll).

${ }^{9} \mathrm{Cf}$. Stéphane Courtois et alii. Le Livre noir $\bar{d}$ u communisme, Paris, Robert Laffont, 1997 , p. 15 et passim.

${ }^{10}$ See Jean de Léry. Viagem à Terra do Brasil (translated by Sérgio Milliet), Rio de Janeiro, Biblioteca do Exército, 1961, p. 181; Carl Waldman. The Atlas of the North American Indian, $3^{\text {rd }}$ ed., New York, Checkmark Books, 2009, p. 20; Pierre Bertaux. África. Desde la prehistoria hasta los años sesenta (translated 
than a politically correct cliché, something just as deviously distorted as that of the "bad European". Mutual respect and constructive selfcriticism are among many other one-of-a-kind Western contributions for humanity as a whole; "seas never before sailed", those are virtues inherited from Greek-Roman culture, and saved, cultivated and promoted by the Catholic Church from its beginnings. ${ }^{11}$ Throughout the Americas, complaints against enslavement, exploitation and bad treatment in general (whether concerning Indians, Africans and mestizos of all kinds) came mostly from Europeans - e.g., Queen Isabella I of Castile (1451-1504), Saint Luis Beltrán (1526-1581) and Saint Peter Claver (1580-1654) - or Americans of European origin, e.g., the abolitionist Harriet Elisabeth Beecher Stowe (1811-1896), the Libertador Simón Bolívar (1783-1830), the Chile's founding Father Bernardo O'Higgins and the historian Dee Brown (19082002). Books such as Beecher Stowe's Uncle Tom's Cabin (1851) and Brown's Bury My Heart at Wounded Knee (1970) have been widely read until today in the three Americas and the rest of the world as well. In terms of constructive self-criticism and positive social impact, they leave nothing to be desired in comparison to the famous Brevisima relación de la destruición de las Indias (1542), written by the Spanish Dominican Priest Bartolomé de Las Casas (1470-1566), concerning the crimes committed by Spanish Conquistadores against the Indians of Central America. To echo Sir Winston Leonard Spencer-Churchill (1874-1965), democracy (by the way another Western invention that thrived especially in North America) "is the worst form of government except for all other forms that have been tried from time to time". No wonder that so many of Western culture's detractors - e.g., Pablo Picasso (1881-1973), John Lennon (1940-1980), Oscar Niemeyer (1907-2012), David Levering Lewis (1936), Amin Maalouf (1947), Giuliano Montaldo (1930) etc. - never considered giving up the "capitalistic and imperialistic" quality of life in the West, in order to reside, as common citizens (that means, without the usual privileges granted by Communist and Islamic ruling classes to their protégés and accomplices in general), in Pyongyang, Havana, Teheran or Rabat.

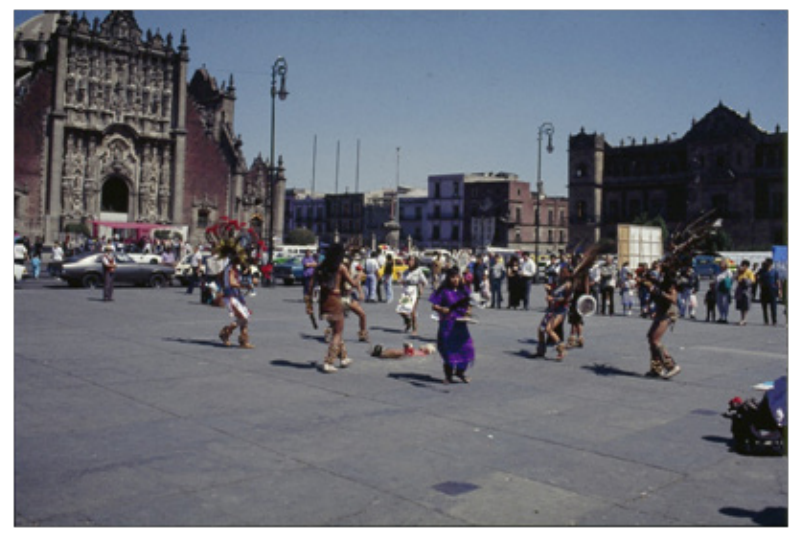

Mexico City, a witness of Las Casas denounced crimes against the Amerindians (Photo taken by the Author).

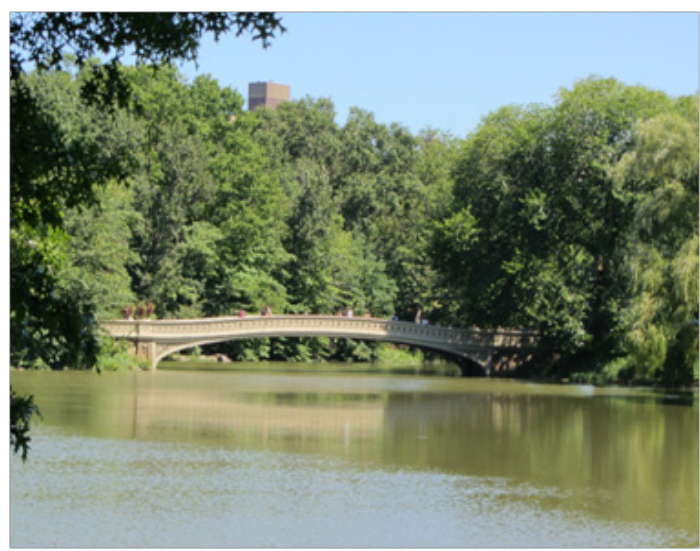

"A working class hero is something to be; if you want to be a hero, you have just to follow me", wrote the ex-Beatle John Winston Lennon in 1970, only three years before moving to an apartment in front of Central Park, one of the most desirable and expensive neighbourhoods in New York. (Photo taken by the Author).

\section{Acknowledgements}

None.

\section{Conflict of interest}

The author declares there is no conflict of interest.

by Manuel Ramón Alarcón), Madrid, Siglo XXI, 1994, p. 133 et passim; Enrique Martínez López. Tablero de Ajedrez. Imágenes del negro heroico en la comedia española y en la literatura e iconografía del Brasil esclavista, Paris, Calouste Gulbenkian, 1998, p. 79 et passim; and José Osvaldo de Meira Penna. O espirito das revoluçães, Rio de Janeiro, Faculdade da Cidade, 1997, p. 333. ${ }^{11}$ See Thomas Woods. How the Catholic Church Built Western Civilization (with new foreword by Cardinal Antonio Cañizares), Washington, Regnery, 2012, p. 1 et passim. 